\title{
Analisis Fuzzy C-Means dan Penerapannya Dalam Pengelompokan Kabupaten/Kota di Provinsi Sulawesi Selatan Berdasarkan Faktor- faktor Penyebab Gizi Buruk
}

\author{
Wahidah Sanusi ${ }^{1}$, Ahmad Zaky ${ }^{1}$, dan Besse Nur Afni ${ }^{1 . a)}$ \\ ${ }^{1}$ Jurusan Matematika, Fakultas Matematika dan Ilmu Pengetahuan Alam \\ Universitas Negeri Makassar \\ a) anggrianinurafni@gmail.com
}

\begin{abstract}
Abstrak. Dalam analisis pengeompokan (cluster), banyak kelompok menjadi suatu masalah yang berarti. Beberapa peneliti memiliki banyak kelompok sesuai dengan kebutuhan dalam penelitiannya. FCM melakukan pengelompokan dengan prinsip meminimumkan fungsi pengelompokannya dimana salah satu parameternya adalah fungsi keanggotaan dalam fuzzy (sebagai pembobot) yang disebut juga dengan fuzzier. Penelitian ini bertujuan untuk mengkaji metode pengelompokan dengan Fuzzy C-Means Clustering dan penerapannya dalam pengelompokan Kabupaten/Kota di Sulawesi Selatan berdasarkan Faktor-faktor Penyebab Gizi Buruk yakni sarana dan tenaga kesehatan, kependudukan, perekonomian yang rendah, serta asupan gizi yang rendah. Dari hasil analisis pengelompokan Fuzzy C-Means dengan 2 cluster diperoleh fungsi objektif sebesar 1079141921,2224. Dimana kelompok pertama terdiri dari 18 kabupaten/kota sedangkan kelompok kedua terdiri atas6 kabupaten.
\end{abstract}

Kata Kunci:Cluster, Fuzzy-C-Means, Fuzzier

Abstract. In the analysis of clustering, many groups became an issue. Some researchers chose many groups that match the needs of their research. FCM performs grouping with the principle of minimising its categorization function where one of the parameters is a membership function in fuzzy (as weighing), also known as with fuzzier. This research aimed to study the methods of grouping with Fuzzy C-Means Clustering and its application in the classification of grouping at Regency/City of South Sulawesi based on factors of Causes of Malnutrition i.e. in terms of facilities and health workers, population, economy, and low nutrient intake that is low. From the results of the analysis of the classification with Fuzzy C-Means with 2 clusters with the objective function respectively is 1079141921.2224. When the first group of 18 district while the second group consists of 6 counties.

Keywords:Cluster, Fuzzy C-Meanas, Fuzzier

\section{PENDAHULUAN}

Queen of Science merupakan sebutan lain matematika sebagai ilmu yang memicu perkembangan ilmu-ilmu lain (Roswati, 2015). Tanpa bantuan dari ilmu matematika, perkembangan dibidang teknik, ekonomi, sosial, sains dan kesehatan tidak akan berkembang seperti sekarang ini, begitu pula dengan bidang statistika dan terapannya yang saat ini berkembang sangat pesat. Salah satu metode statistika yang banyak digunakan dalam pengelompokan yaitu metode clustering.

Clustering adalah suatu metode pengelompokan berdasarkan ukuran kedekatan (kemiripan). Clustering berbeda dengan group, kalau group berarti kelompok yang memiliki kondisi yang 
sama. Sedangkan cluster kelompoknya tidak harus sama, pengelompokan didasarkan pada kedekatan dari suatu karakteristik sampel yang ada, salah satunya dengan menggunakan rumus jarak Euclidean. Pengaplikasian cluster sangatlah banyak, hal ini dikarenakan dalam mengidentifikasi suatu permasalahan atau pengambilan keputusan selalu tidak sama persis akan tetapi cenderung memiliki kemiripan saja (Satriyanto, 2015).

Metode clustering pada dasarnya mengoptimumkan pusat cluster (Centroid) (Kusumadewi, 2010). Beberapa metode clustering yang sering digunakan antara lain, yaitu : 1) Berbasis Metode Statistik seperti Hirarchical clustering method dan Non Hirarchical clustering method, 2) Berbasis Fuzzy : Fuzzy C-Means, 3) Berbasis Neural Network : Kohonen SOM, LVQ, dan 4) Metode lain untuk optimasi centroid atau lebar cluster seperti Genetik Algoritma (GA) (Satriyanto, 2015).

Fuzzy C-Means Clustering (FCM) atau dikenal juga sebagai Fuzzy ISODATA, merupakan salah satu metode clustering yang merupakan bagian dari metode Hard K-Means. FCM menggunakan model pengelompokan fuzzy sehingga data dapat menjadi anggota dari semua kelas atau cluster terbentuk dengan derajat atau tingkat keanggotaan yang berbeda antara 0 hingga 1 . Tingkat keberadaan data dalam suatu kelas atau cluster ditentukan oleh derajat keanggotaannya. Teknik ini pertama kali diperkenalkan oleh Jim Bezdek pada tahun 1981 (Kusumadewi, 2010).

Berdasarkan data Dinas Kesehatan Provinsi Sulawesi Selatan tahun 2014, diperoleh angka gizi buruk sebesar 4366 balita, sedangkan pada tahun 2015 di peroleh persentase angka gizi buruk sebesar 8469 balita, yang diperoleh berdasarkan status gizi berat badan dibagi umur yang artinya, terjadi peningkatan sebesar 34.02 persen. Hal ini disebabkan oleh tingkat pemberian ASI eksklusif, jumlah puskesmas, jumlah tenaga kesehatan, keluarga yang berperilaku hidup bersih dan sehat, jumlah penduduk miskin serta rata-rata anggota rumah tangga.

Pada penelitian ini kasus gizi buruk yang terjadi di wilayah Sulawesi Selatan dengan faktor-faktor penyebab yaitu dari pemberian ASI eksklusif, jumlah puskesmas, jumlah tenaga kesehatan, keluarga yang berperilaku hidup bersih dan sehat, jumlah penduduk miskin serta rata-rata anggota rumah tangga. Berdasarkan faktor-faktor inilah yang nantinya akan dijadikan sebagai kriteria pengelompokan dengan menggunakan pendekatan Fuzzy C-Means.

\section{Clustering}

Menurut Agusta (2015), clustering adalah proses pengelompokan objek berdasarkan infomasi yang diperoleh dari data yang menjelaskan hubungan antar objek dengan prinsip untuk memaksimalkan kesamaan antar anggota satu kelas dan meminimumkan kesamaan antar kelas atau cluster. Menurut Kusumadewi (2010), terdapat dua tahapan yang harus dilakukan dalam analisis cluster, yaitu : 1) Memutuskan apakan jumlah cluster ditentukan atau tidak, dan 2) Menentukan algorita yang akan digunakan dalam clustering. Untuk memutuskan berapa jumlah cluster yang akan dibentuk. Dalam melakukan analisis clustering dapat memilih satu diantara dua pendekatan yaitu 1) Hard Clustering atau 2) Soft Clustering. Pemilihan pendekatan yang digunakan tergantung jenis data yang akan dikelompokkan. Hard clustering digunakan apabila data berbentuk crisp sedangkan soft clustering digunakan apabila data berbentuk fuzzy (Agusta, 2015).

\section{Fuzzy C-Means}

Fuzzy C-Means (FCM) adalah salah satu teknik peng-cluster-an data yang mana keberadaan tiaptiap titik data dalam suatu cluster ditentukan oleh derajat keanggotaannya. Teknik ini pertama kali diperkenalkan oleh Jim Bezdek pada tahun 1981 (Kusumadewi, 2006).

Fuzzy Cluster Means (FCM) merupakan algoritma yang digunakan untuk melakukan clustering data sesuai berdasarkan keberadaan tiap-tiap titik data sesuai dengan derajat keanggotaannya (Ahmadi \& Hartati, 2013). Berikut adalah algoritma clustering FCM: 
1. Input data yang akan di-cluster $\mathrm{X}$, berupa matriks berukuran $\mathrm{n} \times \mathrm{p}$ ( $\mathrm{n}=\mathrm{jumlah}$ sampel data, $\mathrm{p}=$ atribut setiap data). $\mathrm{X}_{\mathrm{kj}}=$ data sampel ke-k $(k=1,2, \ldots, n)$, atribut ke-j $(j=$ $1,2,3, \ldots, m)$.

2. Menentukan:

a) Jumlah cluster $=c$;

b) Pangkat pembobot $=m$;

c) Maksimum iterasi = MaxIter;

d) Error terkecil yang diharapkan $=\xi$;

e) Fungsi Objektif awal $\quad=P_{0}=0$;

f) Iterasi awal $=\mathrm{t}=1$

2. Bangkitkan bilangan random $\left(\mu_{i k}, i=1,2, \ldots, c ; k=1,2, \ldots, n\right)$, sebagai elemen-elemen matriks partisi awal U

$$
U_{0}=\left[\begin{array}{cccc}
\mu_{11}\left(x_{1}\right) & \mu_{12}\left(x_{2}\right) & \cdots & \mu_{1 c}\left(x_{c}\right) \\
\vdots & \vdots & & \vdots \\
\mu_{11}\left(x_{1}\right) & \mu_{12}\left(x_{2}\right) & \cdots & \mu_{n c}\left(x_{c}\right)
\end{array}\right]
$$

Matriks partisi pada fuzzy clustering harus memenuhi kondisi sebagai berikut:

$$
\begin{gathered}
\mu_{i k}=[0,1] ; \quad(1 \leq i \leq c ; 1 \leq k \leq n \\
\sum_{i=1}^{n} \mu_{i k}=1 ; 1 \leq i \leq c \\
0<\sum_{i=1}^{c} \mu_{i k}<c ; 1 \leq k \leq n
\end{gathered}
$$

Hitung jumlah setiap kolom (atribut):

dengan $j=1,2,3, \ldots, m$

$$
Q_{j}=\sum_{i=1}^{c}\left(\mu_{i k}\right)
$$

kemudian hitung:

$$
\mu_{i k}=\frac{\mu_{i k}}{Q_{j}}
$$

3. Hitunglah pusat cluster ke-k: Vij, dimana $i=1,2,3, \ldots, c$ dan $j=1,2,3, \ldots, m$

$$
\begin{aligned}
V_{i j} & =\frac{\sum_{k=1}^{n}\left(\left(\mu_{i k}\right)^{m} * X_{k j}\right)}{\sum_{k=1}^{n}\left(\mu_{i k}\right)^{m}} \\
V & =\left[\begin{array}{ccc}
v_{11} & \cdots & v_{1 m} \\
\vdots & \ddots & \vdots \\
v_{c 1} & \cdots & v_{c m}
\end{array}\right]
\end{aligned}
$$

4. Hitung fungsi objektif pada iterasi ke-t, Pt dengan menggunakan persamaan sebagai berikut:

$$
P_{t}=\sum_{k=1}^{n} \sum_{i=1}^{c}\left(\left[\sum_{j=1}^{m}\left(X_{k j}-V_{i j}\right)^{2}\right]\left(\mu_{i k}\right)^{m}\right)
$$

5. Hitung perubahan matriks partisi:

6. Cek kondisi berhenti:

$$
\mu_{i k}=\frac{\left[\sum_{j=1}^{p}\left(X_{k j}-V_{i j}\right)^{2}\right]^{\frac{-1}{p-1}}}{\sum_{i=1}^{c}\left[\sum_{j=1}^{p}\left(X_{k j}-V_{i j}\right)^{2}\right]^{\frac{-1}{p-1}}}
$$

a) Jika $\left(\left|P_{t}-P_{t-1}\right|<\xi\right)$ atau $(t<$ iterasi maksimal) maka berhenti; 
b) Jika tidak: maka $t=t+1$ kemudian ulang langkah ke-4.

\section{METODOLOGI PENELITIAN}

Penelitian ini menggunakan data sekunder dengan unit pengamatan 24 Kabupaten/Kota di Provinsi Sulawesi Selatan dengan sampel penduduk Sulawesi Selatan yang masuk dalam pendataan berdasarkan kriteria variabel yang digunakan pada penelitian ini di tahun 2016.

Penelitian ini akan mengelompokkan wilayah-wilayah yang memiliki tingkat keanggotaan tertinggi berdasarkan variabel yang digunakan. Variabel yang digunakan merupakan jumlah kasus gizi buruk yang disertai dengan faktor pemberian ASI eksklusif, jumlah puskesmas, jumlah tenaga kesehatan, keluarga yang berperilaku hidup bersih dan sehat, jumlah penduduk miskin serta rata-rata anggota rumah tangga.

Metode yang digunakan merupakan metode clustering dengan metode analisis Fuzzy C-Means yang bertujuan untuk mengelompokkan Kabupaten/Kota di Sulawesi Selatan menjadi kelompokkelompok berdasarkan variabel-variabel yang sudah ditentukan oleh peneliti. Pertama kali dilakukan, yaitu menentukan pusat cluster, yang nantinya akan menandai lokasi rata-rata untuk tiap cluster. Dengan melakukan iterasi untuk memperbaiki pusat cluster dan derajat keanggotaan tiap-tiap titik data, maka akan dilihat bahwa pusat cluster dan derajat keanggotaan akan menuju lokasi titik yang tepat. Pada penelitian ini dilakukan perhitungan manual berdasarkan algoritma Fuzzy C-Means dan kemudian dibandingkan perhitungannya dengan menggunakan software MATLAB R2013a.

\section{HASIL PENELITIAN}

\section{Clustering Data dengan Menggunakan Fuzzy C-Means (FCM)}

1. Menetapkan matriks partisi $U$ berupa matriks berukuran $\mathrm{n} \times \mathrm{p}$ In adalah jumlah sampel data, yaitu $n=24$, dan $p$ adalah parameter/atrbut setiap data, yaitu $p=7) X_{k j}=$ data sampel $\mathrm{ke}-\mathrm{k}(\mathrm{k}=1,2, \ldots, \mathrm{n})$, atribut $\mathrm{ke}-\mathrm{j}(\mathrm{j}=1,2, \ldots, \mathrm{p})$ adapun data yang digunakan ditunjukkan oleh tabel 1 .

2. Menentukan nilai parameter awal
a) Jumlah cluster
$=2$
b) Pangkat pembobot
$=2$
c) Maksimum iterasi
$=100$
d) Error terkecil yang diharapkan $=10^{-5}$
e) Fungsi Objektif awal $=0$
f) Iterasi awal
$=1$

3. Membangkitkan bilangan random $\left(\mu_{i k}, i=1,2, \ldots, c ; k=1,2, \ldots, n\right)$, sebagai elemenelemen matriks partisi awal $\mathrm{U}_{24 \times 2}$

4. Menentukan pusat cluster $V$

Dengan menggunakan rumus $V_{i j}$, diperoleh pusat cluster $V_{2 X 7}$ yang terbentuk pada iterasi pertama adalah:

$$
V_{i j}=\left[\begin{array}{ccccccc}
2402,2716 & 18,5795 & 69,7118 & 138,1839 & 21901,2088 & 2869,0661 & 4,3188 \\
3333,1625 & 17,6601 & 250,6738 & 186,2149 & 22483,5591 & 3995,5492 & 4,3962
\end{array}\right]
$$

5. Menghitung fungsi objektifitas pada iterasi pertama adalah:

Fungsi objektif pada iterasi pertama $P_{l}$ dihitung dengan menggunakan persamaan:

$$
P_{1}=\sum_{k=1}^{24} \sum_{i=1}^{2}\left(\left[\sum_{j=1}^{7}\left(X_{k j}-V_{i j}\right)^{2}\right]\left(\mu_{i k}\right)^{m}\right)=622060071.1301
$$


TABEL 1. Data Balita Gizi Buruk Berdasarkan Faktor-Faktor Penyebab Menurut Kabupaten/Kota Sulawesi Selatan 2016

\begin{tabular}{|c|c|c|c|c|c|c|c|c|c|}
\hline \multirow{3}{*}{ No. } & \multirow{3}{*}{ KABUPATEN } & \multicolumn{7}{|c|}{$\begin{array}{c}\text { Sampel Penduduk Sulawesi Selatan Berdasarkan Kriteria } \\
\text { Variabel Tahun } 2016\end{array}$} & \multirow{3}{*}{ Jumlah } \\
\hline & & ASI & Puskesmas & Dokter & Bidan & PHBS & PM & RART & \\
\hline & & $\mathbf{n}$ & $\mathbf{n}$ & $\mathbf{n}$ & $\mathbf{n}$ & $\mathbf{n}$ & $\mathbf{n}$ & $\mathbf{n}$ & \\
\hline 1 & SELAYAR & 539 & 14 & 38 & 74 & 8000 & 1721 & 4,0 & 10390 \\
\hline 2 & BULUKUMBA & 2600 & 19 & 68 & 132 & 49429 & 3325 & 4,1 & 55577,1 \\
\hline 3 & BANTAENG & 1525 & 13 & 45 & 81 & 10587 & 1753 & 4,1 & 14008,1 \\
\hline 4 & JENEPONTO & 1675 & 18 & 44 & 88 & 12814 & 5532 & 4,4 & 20175,4 \\
\hline 5 & TAKALAR & 1291 & 15 & 78 & 109 & 28065 & 2705 & 4,3 & 32267,3 \\
\hline 6 & GOWA & 3923 & 25 & 171 & 211 & 7689 & 6152 & 4,4 & 18175,4 \\
\hline 7 & SINJAI & 2312 & 16 & 54 & 99 & 48302 & 2251 & 4,5 & 53038,5 \\
\hline 8 & MAROS & 2573 & 14 & 108 & 151 & 8089 & 3902 & 4,5 & 14841,5 \\
\hline 9 & PANGKEP & 3452 & 23 & 100 & 158 & 25000 & 5286 & 4,5 & 34023,5 \\
\hline 10 & BARRU & 982 & 12 & 66 & 100 & 25000 & 1624 & 4,2 & 27788,2 \\
\hline 11 & BONE & 4155 & 38 & 95 & 214 & 27929 & 7509 & 4,4 & 39944,4 \\
\hline 12 & SOPPENG & 1125 & 11 & 75 & 130 & 15573 & 1912 & 4 & 18830 \\
\hline 13 & WAJO & 2455 & 23 & 88 & 137 & 15980 & 2946 & 4,2 & 21633,2 \\
\hline 14 & SIDRAP & 3961 & 14 & 75 & 125 & 37345 & 1592 & 4,2 & 43116,2 \\
\hline 15 & PINRANG & 3297 & 16 & 53 & 164 & 19000 & 3128 & 4,3 & 25662,3 \\
\hline 16 & ENREKANG & 2588 & 13 & 47 & 178 & 17537 & 2698 & 4,5 & 23065,5 \\
\hline 17 & LUWU & 2251 & 21 & 30 & 248 & 25131 & 5058 & 4,6 & 32743,6 \\
\hline 18 & TANA TORAJA & 1621 & 25 & 54 & 216 & 20341 & 2842 & 4,4 & 25103,4 \\
\hline 19 & LUWU UTARA & 4826 & 21 & 44 & 197 & 15103 & 4375 & 4,3 & 24570,3 \\
\hline 20 & LUWU TIMUR & 1455 & 14 & 63 & 186 & 15000 & 2108 & 4,3 & 18830,3 \\
\hline 21 & $\begin{array}{l}\text { TORAJA } \\
\text { UTARA }\end{array}$ & 1922 & 6 & 58 & 185 & 40000 & 3302 & 4,6 & 45477,6 \\
\hline 22 & MAKASSAR & 8194 & 15 & 1239 & 367 & 2000 & 6678 & 4,4 & 18497,4 \\
\hline 23 & PARE-PARE & 772 & 43 & 65 & 114 & 18400 & 802 & 4,5 & 20200,5 \\
\hline \multirow[t]{2}{*}{24} & PALOPO & 827 & 11 & 109 & 107 & 25513 & 1502 & 4,6 & 28073,6 \\
\hline & SULSEL & 60321 & 440 & 2867 & 3771 & 517827 & 80703 & 104,3 & 666033 \\
\hline
\end{tabular}

6. Hitung perubahan matriks partisi U:

Perubahan matriks partisi U dihitung menggunakan persamaan: 
7. Mengecek kondisi berhenti:

$$
\mu_{i k}=\frac{\left[\sum_{j=1}^{p}\left(X_{k j}-V_{i j}\right)^{2}\right]^{\frac{-1}{p-1}}}{\sum_{i=1}^{c}\left[\sum_{j=1}^{p}\left(X_{k j}-V_{i j}\right)^{2}\right]^{\frac{-1}{p-1}}}
$$

Karena $\left.\left|P_{1}-P_{0}\right|=|622060071.1301-0|=622060071.1301>\xi\right)$ dalam hal ini $10^{-5}$, dan iterasi $=1<$ MaxIter(100), maka proses dilanjutkan ke iterasi ke-2 $(\mathrm{t}=2)$.

Iterasi dilanjutkan hingga diperoleh $\left|\mathrm{P}_{\mathrm{t}}-\mathrm{P}_{\mathrm{t}-1}\right|<\epsilon$, atau $t>$ MaxIter. Dengan menggunakan bantuan Software MATLAB R2013a, hasil perhitungannya adalah pusat cluster atau center, derajat keanggotaan atau matriks $U$ serta nilai fungsi tujuan atau Fungsi Objektif.

Hasil pertama yaitu hasil perhitungan nilai fungsional dan diperoleh bahwa diperlukan sebanyak 55 kali iterasi sebelum memperoleh solusi optimal bagi nilai fungsional $J_{m}(U, V)$ sebesar 1079141921.2224.

Hasil yang kedua, yaitu hasil perhitungan dari nilai-nilai $V_{i j}$ sebagai berikut :

$$
V_{i j}=\left[\begin{array}{ccccccc}
2464,040 & 18,879 & 127,136 & 159,978 & 15400,083 & 3341,338 & 4,326 \\
2642,887 & 15,259 & 72,093 & 141,534 & 39836,313 & 2971,678 & 4,366
\end{array}\right]
$$

Nilai-nilai ini merupakan nilai dari "koordinat" titik pusat ke-2 cluster.

Hasil yang ketiga, yaitu hasil perhitungan dari nilai-nilai $U_{i k}$. Berdasarkan nilai-nilai $U_{i k}$ yang diperoleh, maka dapat disajikan hasil pengelompokan pada tabel 2.

TABEL 2. Hasil Pengelompokan Kabupaten/Kota

Provinsi

Kabupaten Selayar, Kabupaten Bantaeng, Kabupaten

Jeneponto, Kabupaten Gowa, Kabupaten Maros,

Kabupaten Pangkep, Kabupaten Barru, Kabupaten

Soppeng, Kabupaten Wajo, Kabupaten Pinrang,

Kabupaten Enrekang, Kabupaten Luwu, Kabupaten Tana

Toraja, Kabupaten Luwu Utara, Kabupaten Luwu Timur,

Kota Makassar, Kota Pare-pare, Kota Palopo

Kabupaten Bulukumba, Kabupaten Takalar, Kabupaten

Sinjai, Kabupaten Bone, Kabupaten Sidrap, Kabupaten

Toraja Utara

Kabupaten/Kota yang termasuk ke dalam kelompok 1 (cluster 1) adalah kelompok yang memiliki tingkat gizi buruk yang tinggi, sedangkan kelompok 2 (cluster 2) adalah kelompok yang memiliki tingkat gizi buruk yang rendah. Hal ini didasarkan pada nilai-nilai pusat cluster-nya (lihat $V_{i j}$ terakhir). Jika dilihat dari segi asupan gizi dan kependudukannya, cluster 2 lebih banyak dibandingkan dengan cluster 1 . Artinya masyarakat/penduduk yang terdapat di daerah tersebut (cluster 2) asupan gizinya lebih terpenuhi dan jumlah penduduknya lebih banyak yang ber-PHBS dibandingkan dengan masyarakat/penduduk di daerah cluster 1. Sedangkan, jika dilihat dari segi sarana dan tenaga kesehatannya, cluster 1 lebih banyak dibandingkan cluster 2. Artinya, Kabupaten/Kota yang berada dalam cluster 1 jumlah masyarakat/penduduknya lebih banyak yang menderita penyakit, dalam hal ini gizi buruk dibandingkan dengan Kabupaten/Kota yang berada di cluster 2. Karena semakin banyak jumlah sarana dan tenaga kesehatan dalam suatu daerah (Kabupaten/Kota), maka semakin banyak pula masyarakat/penduduk yang berada di daerah tersebut yang menderita suatu penyakit. Sehingga perlu disediakannya sarana dan tenaga kesehatan yang lebih banyak. 


\section{PEMBAHASAN}

Pada penelitian sebelumnya tentang Pengelompokan Kabupaten Kota di Provinsi Jawa Tengah dengan Fuzzy C-Means Clustering yang secara konseptual dibahas oleh Risqiyani dan Kesumawati (2016) dalam artikelnya mengangkat kasus mengenai gizi buruk yang disebabkan oleh faktor sarana dan ketenagakerjaan kesehatan serta faktor kependudukan. Yang kemudian kasus gizi terburuk tertinggi di wilayah-wilayah Jawa Tengah ini dikelompokkan berdasarkan faktor-faktor penyebabnya. Di artikel lain yang dibahas oleh Dewi dan Budiantara (2012) meneliti tentang faktor-faktor yang mempengaruhi angka gizi buruk di Jawa Timur yakni ibu yang memeriksakan kehamilan, balita yang mencukupi kebutuhan protein, balita yang mendapatkan vitamin A, rumah tangga yang mengakses Air bersih, bayi lahir rendah dan rumah tangga miskin.

Penelitian tentang gizi buruk juga telah dilakukan oleh beberapa peneliti diantaranya Ramadani, dkk (2013) membahas mengenai faktor-faktor yang mempengaruhi gizi buruk balita di Jawa Tengah menggunakan metode Spatial Durbin Model dengan faktornya adalah pemberian ASI eksklusif, bayi lahir dengan berat badan rendah (BBLR), tempat tinggal dengan kategori rumah sehat, akses air bersih, kepemilikan fasilitas BAB, dan pemberian imunisasi lengkap.

Sementara dalam penelitian ini dijelaskan mengenai penggunaan metode fuzzy dalam hal ini menggunakan metode Fuzzy C-Means Clustering yang diperoleh dari penelitian Risqiyani. Kemudian, metode FCM tersebut dikaji dengan melakukan penurunan tertentu untuk memperoleh Algoritma Fuzzy C-Means Clustering nya. Setelah itu disimulasikan dengan menggunakan data yang diperoleh dari Dinas Kesehatan Provinsi Sulawesi Selatan untuk memperoleh pengelompokan Kabupaten/Kota yang mana termasuk kedalam faktor penyebab Gizi Buruk.

\section{KESIMPULAN}

Berdasarkan hasil penelitian dapat disimpulkan bahwa clustering data dengan menggunakan Fuzzy C-Means (FCM) adalah :

- Banyaknya cluster yang terbentuk adalah 2 cluster.

- Derajat keanggotaan yang terlihat menunjukkan nilai yang cenderung mendekati satu kelompok yang sama, sehingga suatu data memiliki dua atau lebih kelompok yang berbeda. Hal ini disebut dengan overlapping clustering.

- Pengelompokan Kabupaten/Kota di Provinsi Sulawesi Selatan menghasilkan 18 kabupaten yang masuk ke dalam cluster-1 dan 6 kabupaten yang masuk ke dalam cluster2 .

- Fuzzy C-Means Clustering dapat digunakan untuk mengelompokkan Kabupaten/Kota di Sulawesi Selatan berdasarkan faktor-faktor penyebab gizi buruk di Provinsi Sulawesi Selatan untuk waktu berikutnya.

Perlu dikaji lagi mengenai penanganan kasus gizi buruk di Indonesia, khususnya di Provinsi Sulawesi Selatan. Dapat dilihat dari Kabupaten/Kota yang memiliki nilai penderita kasus gizi buruk yang tinggi perlu adanya perhatian khusus agar untuk tahun-tahun berikutnya nilai tersebut semakin naik. Sebagai bahan kajian pemerintah untuk meningkatkan sumber daya manusia. Selain itu, sebaiknya dilibatkan faktor-faktor lain yang mempengaruhi gizi buruk di Provinsi Sulawesi Selatan dengan data yang terbaru dan dengan software lain yang .

\section{DAFTAR PUSTAKA}

Agusta Y. (12 Juni 2015). Clustering. https://yudiagusta.wordpress.com/clustering/. diakses tanggal 12 Mei 2017. 
Ahmadi, A. \& Hartati, S. (2013). Penerapan Fuzzy C-Means dalam Sistem Pendukung Keputusan untuk Penentuan Penerima Bantuan Langsung Masyarakat (BLM) PNPM-MPd (Studi Kasus PNPM-MPd Kec. Ngadirojo Kab. Pacitan). Berkala MIPA. 23 (3). 264-273.

Dewi, R.K. \& Budiantara, I.N. (2012). Faktor-Faktor yang Mempengaruhi Angka Gizi Buruk di Jawa Timur dengan Pendekatan Regresi Nonparametrik Spline. Jurnal Sains Dan Seni ITS. 1(1). 177-182.

Efiyah U. (2014). Penerapan Algoritma Fuzzy C-Means Untuk Pengelompokan Harga Gabah di Tingkat Penggilingan Berdasarkan Kualitas Gabah. (Skripsi, tidak dipublikasikan). Universitas Islam Negeri Maulana Malik Ibrahim.

Kusumadewi \& Purnomo. (2010). Aplikasi Logika Fuzzy untuk Pendukung Keputusan. Edisi 2. Graha Ilmu: Yogyakarta.

Kusumadewi S, Hartati S, Harjoko S, \& Wirdoyo R. (2006). Fuzzy Multi-attribute Decision Making. Yogyakarta : Penerbit Graha Ilmu.

Ramadani I.R., Rahmawati R., Hoyyi A. (2013). Analisis Faktor-Faktor yang Mempengaruhi Gizi Buruk Balita di Jawa Tengah dengan Metode Spatial Dubin Model. Jurnal Gaussian. 2(4). 333-342.

Risqiyani, T.A dan Kesumawati, A. (2016). Pengelompokan Kabupaten Kota di Provinsi Jawa Tengah dengan Fuzzy C-Means Clustering. Seminar Nasional Matematika dan Pendidikan Matematika (pp.179-186). Yogyakarta, Indonesia : Universitas Negeri Yogyakarta.

Roswati, D. (3 April 2015). Mathematics as The Queen of Science. https:// dederoswati.blogspot.co.id./2015/07/mathematics_as_queen-of-science_9.html? $\mathrm{m}=1$. diakses tanggal 12 Oktober 2017.

Satriyanto, E. (25 Maret 2015). Sebuah catatan ringkas aplikasi statistic (Clustering). Kangedi.lecturer.pens.ac.id. diakses tanggal 12 Oktober 2017. 